\title{
India's just deserts
}

\section{The nuclear technology transfer deal agreed by the United States and India makes some sense on its own merits - but it leaves international non-proliferation efforts in disarray.}

'S miling Buddha' was the codename for India's first nuclear bomb test in 1974 . He must be grinning widely this week after Manmohan Singh, India's prime minister, reached a nuclear cooperation deal with US President George W. Bush.

The agreement would end a three-decade-old ban on US exports of nudear technology or fuel to India. The United States will also move to amend international rules that permit nuclear exports only to countries that allow International Atomic Energy Agency (IAEA) safeguards on all their nuclear facilities. These rules were created in response to India's 1974 test, which used plutonium supplied by Canada.

A joint statement issued by Bush and Singh (see page 446) said that "as a responsible state with advanced nuclear technology, India should acquire the same benefits and advantages as other such states". The substitution of the phrase "nuclear weapons state" for "state with advanced nuclear technology" would have rendered the language more accurate, as the agreement is tantamount to a de facto admission of India into the established nuclear-weapons club of the United States, Russia, China, France and the United Kingdom.

This is a very big deal. It flies in the face of the 1970 Nuclear NonProliferation Treaty (NPT). Under the treaty, states that were not already nuclear-weapons states agreed not to develop weapons, and in return are given access to nuclear-power technologies and fuels, under the oversight of the IAEA. As part of the bargain, the nuclear weapons states also agreed to progressively disarm.

India is not a member of the NPT, and it deserves some credit for the consistency of its nuclear policies. As early as 1955, it was calling unsuccessfully for a global ban on nuclear testing. Whereas Iraq and North Korea each signed the treaty and went on to surreptitiously attempt to develop nuclear weapons, India has refused to sign, arguing that existing nuclear powers should first demonstrate their commitment to reducing their own arsenals.
That is one reason why it would be simplistic to say that extending nuclear cooperation to India is fundamentally wrong. India has not acted outside international law. Arguably, if Britain and France can justify maintaining nuclear weapons, the world's largest democracy has a strong case for being accepted as a nuclear-weapons state.

Unlike its neighbour Pakistan, India has acted responsibly to prevent the proliferation of its own nuclear technology. The deal with the United States will also be a boon to the growth of India's nuclear power sector - although some Indian scientists fear that they may now become unnecessarily dependent on US technology. That is seen as a setback in a country that prides itself on its independent scientific and technical capacity (see India Outlook, page 477).

Nonetheless, the sight of Singh and Bush toasting India's nuclear future must have left Brazil, Argentina and South Africa which each abandoned nuclear weapons and signed up to the NPT - feeling short-changed.

Indeed, the bilateral agreement between India and the United States could deal a ham-
"The agreement between India and the United States seems to reflect the Bush administration's desire to sideline the Non-Proliferation Treaty." mer blow to the NPT. This May, a review conference of the treaty made little headway, and the latest agreement seems to reflect the Bush administration's desire to sideline the treaty altogether. In its place, the administration proposes non-proliferation à la carte, with the menu determined by the United States' ever-changing geopolitical interests.

Doubts about the feasibility of this approach should weigh heavily on the minds of US legislators as they consider the changes to existing law needed to implement the Bush-Singh agreement. The Indian deal may be defensible in its own terms - but the overall philosophy behind it is a recipe for further nuclear proliferation.

\section{Born to be in Brussels}

\section{The proposed European Research Council will be safest under the wing of the European Commission.}

V / hatever happens over the next few months in budget negotiations for the European Union's Seventh Framework Programme for research, there now seems to be widespread political acceptance that the European Research Council (ERC) should be established as a funding body for the continent's researchers in the sciences and humanities.

The most visible step so far in the creation of the ERC occurred last week when the 22 members of its scientific board were named (see www.europa.eu.int/comm/research/press/2005/pr1807en.cfm). The European Commission's selection committee for the board did a good job, combining strong scientific credibility with a reasonable geographical balance. The commission now needs to build on this success in its creation of a well-crafted agency.

Contrary to the wishes of some member states, the ERC's foot soldiers should not primarily be seconded from national agencies; they should be independently recruited. To keep the disciplinary programmes vital and responsive, they should be led by scientists from research institutions. And above the heads of the ERC executive staff, the agency should be placed firmly in the hands of the commission during its first few years, rather than be controlled more directly by member states.

Such a structure will be not unlike that of the US National Science 
Foundation (NSF). It is not a perfect system, but it has served US science well for more than 50 years and it has the sort of autonomy to which the ERC should aspire. All would agree that, like the NSF, the ERC should be a competitive organization for bottom-up basic research, funding researchers from across all disciplines and from across the continent, solely on the basis of excellence.

But 'autonomy' means different things to different people. For some, it means as complete a dissociation as is possible from the European Commission. History might seem to support this argument, even though it will be the commission that will be footing the bill, likely to be up to $€ 1.5$ billion (US $\$ 1.8$ billion) per year. The commission's customary bureaucracy has never failed to alienate researchers.

But the commission can in this case play a useful role in sheltering the new-born agency from interference by competing national interests. Opponents of management by the commission have latched on to a hitherto unused article in the rules governing commission research, which allows a separate agency to be set up to run a particular programme. At an informal meeting of research ministers of the European Union's 25 member states in Cardiff earlier this month, opinion was equally divided between the merits of this and a commission-led agency.

It may already be too late for the more independent agency to be in place at the start, if the ERC is to be launched in 2007 as planned. Its establishment and location would require approval by both the European council of ministers and the European parliament - bodies that stretched out the decision to create the somewhat analogous European food agency over three years in an acrimonious and heavily politicized struggle.

Even more dangerously, there is a strong possibility that the agency would establish a decision-making board filled with national representatives. In contrast, a commission-run agency would have only a five-strong steering committee to ensure that it executes appropriately the will of its scientific council.

European experience demonstrates time and again that when the European Union's member nations get too dosely involved, their diverse individual goals distort agendas and delaydecisions. One of the commission's cardinal roles is to shelter the implementation of European policies from the distorting effects of national interests.

The best way forward is therefore to set up the ERC as a commission-led agency with the option of switching to a more independent operation "Experience demonstrates time and again that when Europe's member nations become involved, their individual goals distort agendas and delay decisions." later if it proves desirable. The commission would then have time to prove that it can run an agency capable of executing the desires of its scientific council without debilitating bureaucracy. Better to live in hope than to sacrifice the ERC to the certain buffeting between the conflicting fancies of Europe's 25 member states.

\section{Independence at the top}

The US Food and Drug Administration badly needs some strong and stable leadership.

$\bigcirc$ n 18 July, the US Senate finally confirmed Lester Crawford as commissioner of the Food and Drug Administration (FDA). Crawford has been acting commissioner since March 2004. This critically important agency has lacked a confirmed leader for more than half of President George W. Bush's tenure - and the cracks are beginning to show.

Crawford, a pharmacologist, veterinarian and member of the Institute of Medicine, has previously held senior positions at both the FDA and the Department of Agriculture. In 2002 and 2003 he was the FDA's deputy commissioner. Patient advocates praise him for trying to improve the predictability and efficiency of cancer-drug approvals. And he has expertise in food safety and animal health relevant skills in an era of bioterrorism and bird flu.

On some issues, however, Crawford already stands accused of lacking the independence and leadership skills required of the position. One bone of contention, which held up his Senate confirmation for several months, concerns access to an emergency contraceptive. Despite the approval of a panel of outside scientific experts, as well as the FDA's own staff scientists, Crawford had failed to act on an application from the manufacturer to make the 'morning after' contraceptive known as Plan B available over-the-counter. This month, the agency finally promised to make a decision by 1 September. The troubling implication is that until his nomination got bogged down in the Senate, Crawford bent to political pressure from an anti-abortion White House, instead of making a decision based on the best scientific evidence, which concluded that Plan B is safe and effective.

Crawford also seemed to be caught flat-footed last autumn, when the UK authorities shut down a Chiron plant in Liverpool, halving at a stroke last winter's US supply of flu vaccine. The FDA had failed to re-examine the plant after it had contamination problems in 2003 - even after the company reported, two months before it was shut down last October, that millions of doses of flu vaccine had been contaminated.

Additionally, consumer advocates are worried by a recent sharp decline in FDA enforcement actions against false or misleading advertising. FDA warning letters to pharmaceutical companies fell by $70 \%$ between January 2002 and December 2004, at a time when drug companies were pouring unprecedented sums into advertising directly aimed at consumers. Crawford was the FDA's top manager for much of this period.

Now his position has been confirmed, Crawford has more leverage, and he should have plenty of opportunities to demonstrate the leadership that the agency requires. Another flu-vaccine shortage looms this winter, and bird flu threatens the prospect of a 1918-style pandemic. Public suspicion of the pharmaceutical industry continues to grow in the wake of the Vioxx withdrawal (see Business, page 459), amid evidence that drug-makers are still slow to file evidence about the safety of established products with the regulator. In the face of these challenges, Crawford has to prove that he is the right man for the job. He could start by doing the right thing by Plan B. 